\title{
PENGARUH EKSTRAK DAUN BUNGA TAHI AYAM (Tagetes erecta) TERHADAP KEMATIAN LARVA Aedes aegypti
}

\section{EFFECT OF MARIGOLD FLOWER (Tagetes erecta) LEAVES EXTRACT ON THE Aedes aegypti LARVA MORTALITY RATE}

\author{
Zulfikar $^{1 *}$, Khairunnisa ${ }^{1}$, Yasir $^{2}$ \\ ${ }^{1}$ Jurusan Kesehatan Lingkungan Politeknik Kesehatan Kemenkes Aceh \\ Jl. Soekarno-Hatta Kampus Terpadu Poltekkes Aceh, Darul Imarah Aceh Besar \\ ${ }^{2}$ Balai Penelitian dan Pengembangan Kesehatan Aceh \\ *email: zulfikarkawe@gmail.com
}

\begin{abstract}
ABSTRAK
Pengendalian penularan penyakit Demam Berdarah Dengue (DBD) di Indonesia masih dilakukan secara kimia yaitu menggunakan insektisida golongan organofosfat (malation dan temefos) untuk menurunkan kepadatan vektornya. Upaya pengendalian vektor alternatif yang dilakukan adalah memutus siklus hidup nyamuk pada stadium larva dengan menggunakan bahan-bahan alami yang mudah terurai di alam dan tidak meracuni lingkungan fisik, biologi, dan kimia di sekitarnya. Daun bunga tahi ayam mengandung, semua senyawa tersebut bersifat toksik dan dapat berfungsi sebagai larvasida. Penelitian eksperimen ini dilakukan terhadap larva Aedes aegypti instar III sebanyak 625 larva dengan membagi 5 kelompok perlakuan yaitu kelompok kontrol, kelompok dosis $1 \mathrm{ml}$, kelompok dosis $2 \mathrm{ml}$, kelompok dosis $4 \mathrm{ml}$ dan kelompok dosis $8 \mathrm{ml}$ dalam $200 \mathrm{ml}$ air. Penelitian diulang sebanyak 5 kali. Untuk mengetahui kemaknaan diantara kelompok perlakuan terhadap kematian larva Aedes aegypti dilakukan Analisis Variansi Satu Arah (ANOVA) yang dilanjutkan dengan LSD Test. Rata-rata kematian pada kelompok kontrol adalah 0 larva, pada kelompok $1 \mathrm{ml}$ adalah 4,6 larva, kelompok $2 \mathrm{ml}$ adalah 8,0 larva, pada kelompok 4 $\mathrm{ml}$ adalah 10,2 larva dan pada kelompok $8 \mathrm{ml}$ adalah 13,4 larva. Hasil uji statistik diperoleh $\mathrm{p}=0,000$, sehingga $\mathrm{p}<0,05$ artinya ada perbedaan yang bermakna diantara dosis perlakuan sehingga ekstrak daun bunga tahi ayam dapat mematikan larva Aedes aegypti. Penggunaan ekstrak daun bunga tahi ayam dengan konsentrasi $8 \mathrm{ml}$ merupakan dosis yang memberi efek kematian larva lebih dari 50\% (LC50).
\end{abstract}

Kata Kunci: Aedes aegypti, bunga tahi ayam, larvasida

\begin{abstract}
Control of the transmission of Dengue Hemorrhagic Fever disease in Indonesia is still carried out chemically by using organophosphate (malation and temefos) insecticides to reduce its vector density. Alternative vector control efforts are carried out to break the life cycle of mosquitoes at the larval stage by using natural materials that are easily decomposed in nature and do not poison the surrounding physical, biological, and chemical environment. Marigold flower leaves contain tagetiin, terthienyl, helenian, alkaloids and flavoxanthin; all of these compounds are toxic and can function as larvacides. This experimental study was carried out on 625 Aedesa egypti larvae by dividing them into 5 treatment groups, namely the control group, group of $1 \mathrm{ml}$ dose, group of $2 \mathrm{ml}$ dose, group of $4 \mathrm{ml}$ dose and group of $8 \mathrm{ml}$ dose in $200 \mathrm{ml}$ of water. The study was repeated 5 times. To find out the significance of the treatment groups in case of the mortality of Aedes aegypti larvae, One-Way Variance Analysis (ANOVA) was carried out which was followed by LSD Test. The mean mortality in the control group was 0 larvae, in the $1 \mathrm{ml}$ group was 4.6 larvae, the $2 \mathrm{ml}$ group was 8.0 larvae, in the $4 \mathrm{ml}$ group was 10.2 larvae and in the $8 \mathrm{ml}$ group was 13.4 larvae. The statistical test results obtained $p=0,000$, so that $p$ was $<0.05$ which meant that there was a significant difference between the treatment doses so that marigold flower leaves extract could kill the Aedes aegypti larvae. The use of chicken leaf flower extract with a concentration of $8 \mathrm{ml}$ is a dose that gives the effect of larval death of more than 50\% (LC50).
\end{abstract}

Keywords: Aedes aegypti, marigold flower, larvae 


\section{PENDAHULUAN}

Demam Berdarah Dengue merupakan penyakit infeksi dengan insidensi yang cukup tinggi di Indonesia dan sering berakibat fatal bagi penderitanya.Penyakit ini disebabkan oleh virus Dengue. Berdasarkan profil kesehatan Indonesia Tahun 2016 jumlah penderita DBD yang dilaporkan sebanyak 204.171 kasus dengan jumlah kematian sebanyak 1.598 orang $(I R /$ Angka kesakitan $=78,85$ per 100.000 penduduk dan CFR/ angka kematian $=0,78 \%){ }^{1}$

Aedes aegypti adalah vektor utama di daerah tropik. Di Asia, A. aegypti merupakan satu-satunya vektor yang efektif menularkan virus dengue karena tempat perindukan berada di sekitar rumah dan hidupnya tergantung pada darah manusia. Pada daerah yang penduduknya jarang, A. aegypti masih memiliki kemampuan penularan yang tinggi karena kebiasaan nyamuk tersebut menghisap darah manusia berulangulang pada siang hari. ${ }^{2}$ Oleh karena itu, pengendalian vektor merupakan salah satu cara untuk mencegah transmisi virus .

Pengendalian vektor penular virus dengue yang selama ini dilakukan antara lain pengendalian secara kimia, biologi dan modifikasi lingkungan, akan tetapi pengendalian penularan virus dengue di Indonesia masih banyak dilakukan secara kimia yaitu menggunakan insektisida golongan organofosfat (malation dan temefos) untuk menurunkan kepadatan vektornya. Efektifitas insektisida malation dan temefos ditentukan oleh tingkat kerentanan nyamuk vektor yang menjadi sasaran utamanya. Penggunaan insektisida kimia dalam jangka waktu lama akan memberi efek buruk, yaitu insektisida akan menekan dan menyeleksi serangga vektor sasaran untuk menjadi toleran sampai resisten. ${ }^{3}$

Upaya pengendalian vektor alternatif yang dilakukan adalah memutus siklus hidup nyamuk pada stadium larva dengan menggunakan bahan-bahan alami yang mudah terurai di alam dan tidak meracuni lingkungan fisik, biologi, dan kimia di sekitarnya. ${ }^{4}$

Tanaman bunga tahi ayam atau Tagetes erecta pada jaman dulu banyak digunakan untuk pengobatan luka. Tanaman ini dikenal secara umum sebagai tanaman herbal aromatik tahunan yang tingginya mencapai 0,4-1 m. Bunga tahi ayam mempunyai khasiat obat tradisional dan telahdigunakan oleh banyak masyarakat sebagai obat untuk menyembuhkan penyakit mata, konjungtivitis, pilek, rematik, batuk, pendarahan wasir, dan bisul. ${ }^{5,6}$ Bagian tanaman yang digunakan sebagai obat adalah bunganya. Bunga bisa dikeringkan untuk penyimpanan. Namun, daun dan minyaknya juga berkhasiat untuk obat. Tanaman ini telah banyak digunakan untuk pengobatan. Biasanya digunakan untuk mengobati sakit perut, parasit, diare, penyakit hati, muntah, gangguaan pencernaan, sakit gigi, dan penyakit lainnya. ${ }^{7}$ Kandungan kimia aktif yang ada di bunga tahi ayam adalah tagetiin, terthienyl, helenian, alkaloid dan flavoxanthin, semua senyawa tersebut bersifat toksik dan dapat berfungsi sebagai larvasida. ${ }^{8}$

Melihat komposisi senyawa kimiawi yang terdapat dalam tumbuhan bunga tahi ayam, 
maka daun bunga tahi ayam diduga memiliki potensi sebagai larvasida, sebagai racun kontak dan racun perut. Berdasarkan latar belakang tersebut maka perlu dilakukan kajian sistematis untuk mengetahui efektivitas daun bunga tahi ayam sebagai larvasida A. aegypti.

\section{METODE}

Jenis penelitian adalah bersifat eksperimen yaitu untuk melihat perbedaan dosis yang paling efektif ekstrak daun bunga tahi ayam (T. erecta) dalam membunuh larva $A$. aegypti. Penelitian dilaksanakan di Laboratorium Entomologi Jurusan Kesehatan Lingkungan Poltekkes Kemenkes Aceh pada bulan Mei sampai dengan bulan Agustus Tahun 2018.

\section{Subyek Penelitian}

Subyek yang digunakan adalah larva $A$. aegypti, sebanyak 625 larva, dengan rincian tiap kali pengujian sebanyak 25 ekor untuk 5 perlakuan. ${ }^{9}$

Untuk penelitian eksperimen dengan rancangan acak lengkap, acak kelompok atau faktorial, secara sederhana jumlah replikasi dapat ditentukan dengan rumuskanfederer. ${ }^{10}$

$$
(\mathrm{t}-1)(\mathrm{r}-1)>15 \text {. }
$$

Dari rumus tersebut diperoleh jumlah pengulangan adalah sebanyak 5 kali.

\section{Prosedur Penelitian}

a. Pembuatan ekstrak.

Daun bunga tahi ayam yang berasaldari daerah Banda Aceh dan Aceh Besar diambil secara acak sebanyak 2500 gr. Kemudian proses ekstraksi daun bunga tahi ayam dilakukan dengan metode maserasi. ${ }^{11,12}$

\section{b. Tahap eksperimen}

Larva A. aegypti instar III digunakan sebanyak 625 larva, pemilihan larva instar III dikarenakan memiliki kemampuan dalam menetralisir senyawa-senyawa toksik yang lebih tinggi dibandingkan larva instar I dan II, sedangkan larva instar IV lebih dekat untuk menjadi pupa sehingga penelitian akan menjadi bias. Pemeliharaan nyamuk dilakukan dengan tahapan telur nyamuk A. aegypti ditetaskan pada nampan berisi air jernih. Apabila tubuh larva telah berukuran 4-5 $\mathrm{mm}$, kemudian memiliki ciri-ciri seperti duri-duri dada mulai jelas dan corong pernapasan berwarna cokelat kehitaman maka larva telah masuk pada instar III. Kemudian disiapkan 25 buah plastik cup. Plastik cup tersebut diisi aquades sebanyak 200 ml dan ekstrak daun bunga tahi ayam sesuai dengan taraf konsentrasi yaitu $1 \mathrm{ml}, 2 \mathrm{ml}, 4 \mathrm{ml}$ dan $8 \mathrm{ml}$. Pada setiap plastik cup dimasukkan larva dengan jumlah 25 ekor. Pengamatan kematian larva dilakukan pada selang waktu 1 jam, 2 jam, 3 jam,6 jam, 12 jam, dan 24 jam. Setiap kali pengamatan, dihitung dan dicatat jumlah larva yang mati. Selain itu juga, dicatat kelembapan dan suhu lingkungan. ${ }^{13}$

\section{Analisis Data}

Data hasil pengamatan berupa jumlah larva yang mati dianalisis menggunakan uji One Way Analysis of Variance (ANOVA). Apabila menunjukkan angka yang signifikan, maka akan dilanjutkan dengan uji Least Significant Difference (LSD) pada taraf kepercayaan (a) $5 \%$ untuk mengetahui beda kelompok perlakuan. $^{14}$ 


\section{HASIL}

Tabel 1. Hasil pengukuran suhu kamar, suhu air dan kelembaban udara di laboratorium

\begin{tabular}{ccccc}
\hline No & Pengulangan & Suhu Kamar $\left({ }^{\circ} \mathrm{C}\right)$ & Suhu Air $\left({ }^{\circ} \mathrm{C}\right)$ & Kelembaban $(\%)$ \\
\hline 1 & I & 28 & 25 & 78 \\
2 & II & 27 & 25 & 80 \\
3 & III & 27 & 25 & 78 \\
4 & IV & 29 & 26 & 77 \\
5 & V & 27 & 26 & 79 \\
\hline
\end{tabular}

Pada tahapan eksperimen dilakukan kelembaban udara adalah 77-78\%. Hasil pengukuran suhu kamar, suhu air dan kelembaban ruangan laboratorium, hasil pengukuran disajikan pada tabel 1. Berdasarkan Tabel 1 suhu kamar berada pada kisaran 27-29 eksperimen Pengaruh.

Ekstrak Daun Bunga Tahi Ayam ( $T$. erecta) Terhadap Kematian Larva A. aegypti dapat dilihat pada Tabel 2 berikut:

${ }^{\circ} \mathrm{C}$, suhu air berada direntang $25-26{ }^{\circ} \mathrm{C}$ dan

Tabel 2. Jumlah kematian larva Aedes aegypti setelah 24 jam pengulangan perlakuan pertama sampai kelima perlakuan dan kontrol dengan penambahan ekstrak daun bunga tahi ayam (Tagetes erecta)

\begin{tabular}{|c|c|c|c|c|c|c|}
\hline \multirow{2}{*}{ Pengulangan } & \multirow{2}{*}{$\begin{array}{c}\text { Jumlah } \\
\text { Jentik } \\
\text { Awal }\end{array}$} & \multicolumn{5}{|c|}{ Jumlah Kematian Larva Aedes aegypti } \\
\hline & & Kontrol & Dosis 1ml & Dosis 2ml & Dosis 4ml & Dosis 8m \\
\hline I & 25 & 0 & 2 & 5 & 10 & 17 \\
\hline II & 25 & 0 & 8 & 8 & 9 & 12 \\
\hline III & 25 & 0 & 5 & 10 & 13 & 11 \\
\hline IV & 25 & 0 & 5 & 8 & 8 & 12 \\
\hline $\mathrm{V}$ & 25 & 0 & 3 & 9 & 11 & 15 \\
\hline Rata-rata & 25 & 0,0 & 4,6 & 8,0 & 10,2 & 13,4 \\
\hline
\end{tabular}

Berdasarkan Tabel 2 menunjukkan bahwa rata-rata kematian pada kelompok kontrol adalah 0 larva, pada kelompok dosis $1 \mathrm{ml} \mathrm{4,6}$ larva, kelompok dosis $2 \mathrm{ml} \mathrm{8,0} \mathrm{larva,} \mathrm{pada}$ kelompok dosis $4 \mathrm{ml}$ adalah 10,2 larva dan pada kelompok $8 \mathrm{ml}$ adalah 13,4 larva. Kelompok dosis $8 \mathrm{ml}$ merupakan kelompok dosis dengan rata rata kematian paling besar yaitu 13,4 larva.
Data hasil penelitian tersebut kemudian diuji dengan analisis variansi satu jalan atau One Way ANOVA untuk mengetahui tingkat kemaknaan. pengaruh ekstrak daun bunga Tahi Ayam (T. erecta) terhadap kematian larva $A$. aegypti diantara kelompok eksperimendan diperoleh hasil seperti pada Tabel 3 berikut: 
Tabel 3. Hasil uji statistik One way anova antara dosis ekstrak daun bunga tahi ayam (Tagetes erecta) dengan kematian larva Aedes aegypti

\begin{tabular}{cccccc}
\hline Variabel & Rata - rata & SD & SE & $\mathbf{9 5 \%} \boldsymbol{C I}$ & $\boldsymbol{p}$ Value \\
\hline Kontrol & 0,0 & 0,00 & 0,00 & $0,00-0,00$ & \\
$1 \mathrm{ml}$ & 4,6 & 2,30 & 1,03 & $1,74-7,46$ & \\
$2 \mathrm{ml}$ & 8,0 & 1,87 & 0,84 & $5,68-10,32$ & 0,000 \\
$4 \mathrm{ml}$ & 10,2 & 1,92 & 0,86 & $7,81-12,59$ & \\
$8 \mathrm{ml}$ & 13,4 & 2,51 & 1,12 & $10,28-16,52$ & \\
\hline
\end{tabular}

Berdasarkan hasil uji ANOVA satu arah Uji dilanjutkan kepada Multiple pada tersebut dapat dilihat bahwa terdapat perbedaan bermakna antara dosis ekstrak daun Comparison Test yaitu dengan uji LSD Test bunga tahi ayam dengan kematian larva pada untuk membandingkan tingkat kemaknaan nilai $\mathrm{p}=0,000$. diantara masing-masing kelompok eksperimen sehingga diperoleh hasil seperti pada berikut:

Tabel 4. Hasil uji lanjutan Tukey's HSD test ekstrak bunga kecombrang (Etlingera elatior) Sebagai repellent terhadap nyamuk Aedes aegypti

\begin{tabular}{llcccc}
\hline \multirow{2}{*}{ Kelompok Dosis } & Kelompok Perlakuan & Perbedaan rata-rata & SE & P Value & 95\% CI \\
\hline Kontrol & $1 \mathrm{ml}$ & $-4,60$ & 1,23 & 0,01 & $-7,16--2,04$ \\
& $2 \mathrm{ml}$ & $-8,00$ & 1,23 & 0,00 & $-10,56--5,44$ \\
& $4 \mathrm{ml}$ & $-10,20$ & 1,23 & 0,00 & $-12,76--7,64$ \\
& $8 \mathrm{ml}$ & $-13,40$ & 1,23 & 0,00 & $-15,96--10,84$ \\
\hline $1 \mathrm{ml}$ & Kontrol & 4,60 & 1,23 & 0,01 & $2,04-7,16$ \\
& $2 \mathrm{ml}$ & $-3,40$ & 1,23 & 0,12 & $-5,96--0,84$ \\
& $4 \mathrm{ml}$ & $-5,60$ & 1,23 & 0,00 & $-8,16--3,04$ \\
& $8 \mathrm{ml}$ & $-8,80$ & 1,23 & 0,00 & $-11,36--6,24$ \\
\hline $2 \mathrm{ml}$ & Kontrol & 8,00 & 1,23 & 0,00 & $5,44-10,56$ \\
& $1 \mathrm{ml}$ & 3,40 & 1,23 & 0,01 & $0,84-5,96$ \\
& $4 \mathrm{ml}$ & $-2,20$ & 1,23 & 0,09 & $-4,76-0,36$ \\
& $8 \mathrm{ml}$ & $-5,40$ & 1,23 & 0,00 & $-7,96--2,84$ \\
\hline $4 \mathrm{ml}$ & Kontrol & 10,20 & 1,23 & 0,00 & $7,64-12,76$ \\
& $1 \mathrm{ml}$ & 5,60 & 1,23 & 0,00 & $3,04-8,16$ \\
& $2 \mathrm{ml}$ & 2,20 & 1,23 & 0,09 & $-0,36-4,76$ \\
& $8 \mathrm{ml}$ & $-3,20$ & 1,23 & 0,02 & $-5,76--0,64$ \\
\hline $8 \mathrm{ml}$ & Kontrol & 13,40 & 1,23 & 0,00 & $10,84-15,96$ \\
& $1 \mathrm{ml}$ & 8,80 & 1,23 & 0,00 & $6,24-11,36$ \\
& $2 \mathrm{ml}$ & 5,40 & 1,23 & 0,00 & $2,84-7,96$ \\
& $4 \mathrm{ml}$ & 3,20 & 1,23 & 0,02 & $0,64-5,76$ \\
\hline \multirow{2}{*}{} & & & & &
\end{tabular}

* ada perbedaan signifikan $(<0,05)$ 
Berdasarkan tersebut dapat dilihat bahwa terdapat perbedaan bermakna antara kelompok kontrol dengan kelompok dosis 1 $\mathrm{ml}, 2 \mathrm{ml}, 4 \mathrm{ml}$ dan kelompok dosis $8 \mathrm{ml}$, kemudian antara kelompok dosis $1 \mathrm{ml}$ dengan kelompok dosis $4 \mathrm{ml}$ dan $8 \mathrm{ml}$, kelompok dosis $2 \mathrm{ml}$ dengan kelompok dosis $8 \mathrm{ml}$, kelompok dosis $4 \mathrm{ml}$ dengan dengan kelompok dosis $8 \mathrm{ml}(\mathrm{p}<0,05)$.

\section{PEMBAHASAN}

Daun dan bunga tahi ayam mengandung senyawa karbohidrat, alkaloid, glikosida, flavonoid, tanin, steroid, terpenoid, pyrethrin dan minyak atsiri. Minyak atsiri dihasilkan di dalam tubuh tanaman dan kemudian disimpan dalam berbagai organ. Penelitian menunjukkan bahwa minyak atsiri dibuat dalam kelenjar minyak atsiri. Kelenjar minyak atsiri ada yang terdapat di dalam tanaman (kelenjar internal) dan diluar tanaman (kelenjar eksternal) yang mempunyai efek larvasida. ${ }^{15}$ Minyak atsiri bekerja sebagai larvasida dengan cara mempengaruhi sistem saraf pada serangga dan sistem percernaan pada larva sehingga larva mengalami keracunan perut yang mengakibatkan kematian pada larva. Selain itu flavonoid juga mempengaruhi sistem pernapasan pada serangga, flavonoid yang masuk kedalam tubuh serangga dapat melumpuhkan saraf pernapasan serangga sehingga mengakibatkan kematian. ${ }^{16}$ Tidak hanya untuk larva, penggunaan minyak atsiri dari serai juga efektif untuk nyamuk dewasa Aedes aegypti sebagai penganti malathion dalam pelaksanaan kegiatan fogging. ${ }^{17}$

Dari penilitian ini didapatkan bahwa ekstrak daun bunga tahi ayam dapat dijadikan sebagai agen larvasida. Pada semua kelompok uji yang diberi ekstrak daun bunga tahi ayam terdapat larva yang mati. Jumlah kematian larva nyamuk berbeda-beda pada tiap kelompok, kematian larva lebih banyak pada konsentrasi ekstrak daun bunga tahi ayam yang lebih tinggi (Tabel 2). Jadi pada penelitian ini diperoleh hasil bahwa semakin tinggi ekstrak daun bunga tahi ayam yang dimasukkan dalam percobaan maka semakin tinggi jumlah kematian larva. Kematian larva yang berbanding lurus dengan konsentrasi ekstrak diduga disebabkan oleh jumlah kandungan kimia ekstrak yang semakin banyak. Hasil ini sejalan dengan beberapa penelitian seperti efikasi ekstrak daun dan bunga kecombrang (Etlingera elatior) terhadap larva, dimana ekstrak daun dan bunga mempunyai efek larvasida akumulatif. ${ }^{10}$

Larva instar III digunakan karena larva instar III sudah berumur 2 hari, berukuran 4-5 $\mathrm{mm}$, duri-duri dada mulai jelas, dan mencegah larva berubah menjadi pupa setelah instar IV. Pemaparan ekstrak daun bunga tahi ayam konsentrasi letal pada larva instar III menyebabkan terjadinya kerusakan morfologi pada larva. Secara 
umum pengaruh temefos terhadap larva diawali dengan kejadian kejang-kejang atau tremor. Tremor atau kejang-kejang menyebabkan larva memerlukan energi yang lebih besar akibatnya larva kehabisan energi sehingga menyebabkan paralisis yaitu lumpuh atau bahkan kematian. Proses paralisis pada larva terjadi akibat penimbunan racun pada saraf. Hal ini penyebab terjadinya paralisis atau kelumpuhan bahkan kematian. Pengaruh ini juga terjadi pada penggunaan larvasida alami dari bubuk kopi arabika (Coffea arabica $L)^{18}$. Efek larvasida yang muncul dari ekstrak daun bunga tahi ayam juga mempunyai sistem kerja yang serupa dengan larvasida temefos. ${ }^{19}$

Jumlah rata-rata kematian larva tertinggi diperoleh pada dosis $8 \mathrm{ml}$ yaitu 13,4 larva atau 53,6\%, jumlah ini sudah melampaui $50 \%$ jumlah kematian atau LC50. Jumlah tersebut masih bisa bertambah dengan bertambahnya dosis ekstrak hingga mencapai jumlah kematian hewan uji yang diharapkan oleh WHO yaitu sebanyak $80 \%$. Sehingga upaya pengendalian vektor alternatif dengan menggunakan bahanbahan alami yang mudah terurai di alam dapat digunakan untuk menggantikan bahan kimia yang sangat berbahaya bagi manusia dan lingkungan. ${ }^{20}$

\section{KESIMPULAN}

Penggunaan ekstrak daun bunga tahi ayam dengan konsentrasi $8 \mathrm{ml}$ merupakan dosis yang memberi efek kematian larva lebih dari 50\% (LC50).

\section{SARAN}

Diharapakan untuk terus melakukan penelitian dan pengembangan terhadap larvasida alami salah satunya dengan menggunakan larvasida dari ekstrak daun bunga tahi ayam (Tagetes erecta) untuk membunuh larva A. aegypti sehingga menjadi alternatif larvasida pengganti abate atau temefos.

\section{UCAPAN TERIMA KASIH}

Penulis mengucapkan terima kasih kepada Direktur Poltekkes Kemenkes Aceh, H. Ampera Miko, DN.Com, MM. Ketua Jurusan Kesehatan Lingkungan, Nasrullah, SKM, M.Kes. Dosen dan Staf Jurusan Kesehatan Lingkungan, Kepala Unit Penelitian Poltekkes Kemenkes Aceh, Ismail, SKM, M.Pd. dan semua pihak yang telah ikut membantu dalam pelaksanaan penelitian ini.

\section{DAFTAR PUSTAKA}

1. Kementerian Kesehatan Republik Indonesia. Profil Kesehatan Indonesia.; 2017.

2. Chahaya I. Pemberantasan Vektor Demam Berdarah di Indonesia. USU Digit Libr. 2003:1-8. 
3. Pusat Data dan Surveilans KK. Pusat Data dan Surveilans KK. Bul Jendela Epidemiol. 2010;2.

4. Lidia K, Levina E SS. Deteksi dini resistensi nyamuk Aedes albopictus terhadap insektisida organofosfat di daerah endemis demam berdarah dengue di palu (sulawesi tengah). $M \mathrm{~km}$. 2008;2(3).

5. Kiranmai and Ibrahim M. Anibacterial Potential of Different Extracts of Tagetes erecta Linn. Int $J$ Pharm. 2012;2(1):90-96.

6. Pinem DADP. Identifikasi Komponen Kimia Minyak Atsiri Daun Bunga Tahi Ayam (Tagetes erecta L.) serta Uji Aktivitas Antibakteri dan Antioksidan, Skripsi. 2012.

7. Krishnamurthy., Nagaraj., Malakar, B., Liny. D. Green Synthesis of Gold Nanoparticles Using Tagetes erecta L. (Mari Gold) Flower Extract \& Evaluation of Their Antimicrobial Activities. Int J Pharma Bio Sci 3(1) 212-221. 2012.

8. Zen S, Asih T. Potensi ekstrak bunga tahi kotok (tagetes erecta) sebagai Repellent terhadap nyamuk Aedes aegypti yang aman dan ramah lingkungan. Bioedukasi. 2016:142-149. doi:10.24127/bioedukasi.v8i2.1072

9. World Health Organization. Guidelines for laboratory and field-testing of longlasting insecticidal nets. Who/Htm/Ntd/Whopes/20131. 2013:93. www.who.int/about/licensing/copyright _form/en/index.html.

10. Elisabeth Koraag M, Anastasia H, Isnawati R. Efikasi Ekstrak Daun dan Bunga Kecombrang (Etlingera elatior) terhadap Larva Aedes aegypti. Aspirator. 2016;8(2):63-68.

11. Padmasari P, Astuti K, Warditiani N. Skrining fitokimia ekstrak etanol $70 \%$ rimpang bangle. J Farm Udayana.
2013;2(4):1-7.

12. Siregar B. Daya Antibakteri Ekstrak Buah Mahkota Dewa (Phaleria macrocarpa (Scheff.) Boerl) terhadap Pertumbuhan Streptococcusmutans.(In Vitro), Skripsi. 2011.

13. Fuadzy H, Marina R. Potensi Daun Dewa (Gynura pseudochina (1.) Dc.) Sebagai Larvasida Aedes aegypti ( linn .) Potency of Gynura pseudochina ( L .) DC . Extract as Aedes aegypti. Aspirator. 2012;4(April):7-13.

14. Dahlan MS. Statistik Untuk Kedokteran Dan Kesehatan. Edisi 4. Jakarta: Salemba Medika; 2016.

15. Notes N, Suyasa ING, Dewi C, Hana W. Pemanfaatan daun dan akar tahi kotok sebagai insektisida nyamuk Aedes aegypti. J Skala Husada. 2011.

16. Pamungkas RW, Syafei NS, Soeroto AY. Perbandingan Efek Larvasida Minyak Atsiri Daun Cengkeh ( Syzygium aromaticum L .) Varietas Zanzibar dengan Temephos terhadap Larva Nyamuk Aedes aegypti Abstrak. Pharm Sci Res. 2017;4(1):0-5.

17. Zulfikar, Aditama W, Sitepu FY. The effect of lemongrass ( Cymbopogon nardus ) extract as insecticide against Aedes aegypti. Int $J$ Mosq Res. 2019;6(1):101-103.

18. Aditama W, Zulfikar, Sitepu FY. The effectiveness of arabica coffee (Coffea arabica L) grounds on mortality and growth of Aedes aegypti Larva. Int J Mosq Res. 2019;6(1):34-37.

19. Yulidar, Hadifah Z. Kerusakan larva Aedes aegypti ( Linn . ) setelah terpapar temefos pada fase larva instar 3 ( L3 ). $J$ Buski. 2014;5(1):23-28.

20. Barodji. Bionomik Vektor dan Situasi Malaria di Kecamatan Kokap, Kabupaten Kulon Progo, Yogyakarta. J Ekol Kesehat. 2013. 